OPEN ACCESS

ISSN 2338-445X (online) ISSN 2527-9246 (print)

Edited by

Sulikah Asmorowati

Reviewed by:

Rutiana Dwi Wahyunengseh and Tri

Yuniningsih

${ }^{*}$ Correspondence:

Yuni Lestari

yunilestari@unesa.co.id

Published: 29 September 2021

Citation:

Lestari Y. et.al (2021)

Problematics of Affirmative

Action Policy Implementation

of Women's Representation

Quota in Surabaya City

Election.

JKMP(Jurnal Kebijakan dan

Manajemen Publik). 9:2.

doi: $10.21070 / j k m p . v 9 i 2.1580$

\section{Problematics of Affirmative Action Policy Implementation of Women's Representation Quota in Surabaya City Election}

\section{Problematika Implementasi Kebijakan Affirmative Action Kuota Keterwakilan Perempuan pada Pemilu Kota Surabaya}

\author{
Yuni Lestari*, Gading Gamaputra, Firdausi Nuzula
}

Universitas Negeri Surabaya

\section{ABSTRACT}

The development of an increasingly modern era is no longer a guarantee that a society's culture can be freedom from patriarchy as a whole. The women's equality has increasingly opened up opportunities for women to be active in both the domestic and public areas. The policy for affirming the quota for women's representation was also formulated by following developments. The 30\% quota policy for women's representation in political parties is one of the affirmative policies in realizing women's equality in politics in Indonesia. By using descriptive quantitative research methods, this study tries to describe how the implementation of the affirmation policy on the quota of women's representation can work. The results that can be obtained in this study include: (1) in every election process, both the registration process for prospective DPRD members, the process of establishing a temporary candidate list (DCS) and the process of determining the permanent candidate list (DCT) as a whole has complied with quota of $30 \%$ women's representation (2) However, it cannot be denied that at every stage of implementation of the policy, there are still many problem.

Keywords: affirmative action, affirmative policy, election, women politik

\section{PENDAHULUAN}

Berbicara mengenai partisipasi perempuan, tentunya sudah tidak asing lagi ditelinga kita. Bentuk partisipasi perempuan ini, kemudian dikorelasikan dengan hak berpolitik bagi perempuan. Saat ini, banyak perempuan-perempuan yang telah terlibat dan terjun langsung ke ranah politik. Pernyataan ini kemudian dibuktikan dengan meningkatnya jumlah keterwakilan perempuan di Kursi Dewan Perwakilan Rakyat (Komisi Pemilihan Umum RI, 2019). Secara lebih lanjut, Samuel P. Huntington dan Joan M. Nelson menjelaskan bahwa partisipasi politik merupakan serangkaian aktivitas yang dilakukan oleh setiap warganegara sebagai individu atau pribadi yang memiliki hak untuk turut serta dalam mempengaruhi proses pembuatan kebijakan oleh pemerintah (Budiardjo, 2010). Hal ini tentunya juga berlaku pada hak berpolitik bagi perempuan. 
Pentingnya partisipasi perempuan di ranah politik, tentunya bertujuan agar semakin banyak anggota parlemen perempuan yang ikut berpartisipasi, maka semakin besar kemungkinan isu-isu perempuan seperti pendidikan, kesehatan, reproduksi, perlindungan kerja, dan lain sebagainya dapat diperjuangkan di tingkat kebijakan publik. Dalam menarik partisipasi perempuan untuk terjun ke ranah politik, tentu saja tidak mudah untuk dilakukan. Perlu banyak perjuangan yang harus dilakukan. Salah satu bentuk perjuangan yang dimaksudkan yaitu melalui implementasi kebijakan pada Undang-Undang Nomor 12 Tahun 2003 Tentang Pemilihan Umum Anggota Dewan Perwakilan Rakyat, Dewan Perwakilan Daerah, dan Dewan Perwakilan Rakyat Daerah (Ihromi, T. O., Irianto, S., \& Achie SudiartiLuh, 2006).

Perlu diketahui bahwa Undang-Undang Tahun 2003 tersebut, seperti yang telah dijelaskan diatas merupakan undang-undang yang pertama kali menjamin dan menjadi payung hukum bagi perempuan untuk dapat berpartisipasi di kursi legislatif melalui kebijakan 30\% (tiga puluh persen) keterwakilan perempuan. Kebijakan ini diberlakukan bagi setiap partai politik yang akan mengajukan bakal calon anggota legislatif, tepatnya tertuang pada Pasal 65 ayat (1). Namun, tidak hanya disini saja. Undang-undang PEMILU mengalami beberapa kali revisi mulai Undang-Undang No. 8 Tahun 2012 Tentang Pemilihan Umum Anggota Dewan Perwakilan Rakyat, Dewan Perwakilan Daerah, dan Dewan Perwakilan Rakyat Daerah, sampai dengan Undang-Undang No. 7 Tahun 2017 Tentang Pemilihan Umum.

Walaupun peraturan tentang PEMILU dari masa ke masa mengalami perubahan, namun ketentuan tentang kuota keterwakilan perempuan dalam partai politik masih dalam ketetapan yang sama yakni 30\% keterwakilan perempuan. Pada Undang-Undang No. 7 Tahun 2017 Tentang Pemilihan Umum Pasal 173 pada ayat (2) menyatakan untuk menyertakan paling sedikit 30\% (tiga puluh persen) keterwakilan perempuan pada keterwakilan perempuan pada kepengurusan partai politik tingkat pusat. Hal tersebut dapat disimpulkan bahwa setiap partai politik harus menyertakan sekurang-kurangnya 30\% (tiga puluh persen) keterwakilan perempuan untuk ikut berpartisipasi dalam kepengurusan partai politik di tingkat pusat, dan ketentuan kuota 30\% (tiga puluh persen) juga berlaku di tingkat kabupaten atau kota ketika penyusunan daftar calon legislatif. Namun faktanya beberapa daerah pemilihan di Kota Surabya belum terpenuhi. Hal tersebut dapat dilihat pada tabel di bawah ini:

Tabel 1.1

Persentase Keterwakilan Perempuan

\begin{tabular}{ccc}
\hline No & Daerah Pemilihan & Persentase Keterwakilan \\
\hline 1. & Surabaya 1 & $27 \%$ \\
2. & Surabaya 2 & $54 \%$ \\
3. & Surabaya 3 & $33 \%$ \\
4. & Surabaya 4 & $30 \%$ \\
5. & Surabaya 5 & 22\% \\
\hline
\end{tabular}

Sumber: Komisi Pemilihan Umum Kota Surabaya (2014)

Berdasarkan Tabel 1.1 diatas, dapat dijelaskan bahwa Keberadaan undang-undang pemilu sangat membawa dampak pada peningkatkan jumlah partisipasi perempuan dalam pemilihan umum. Khususnya, pada Pemilihan Umum Anggota Dewan Perwakilan Rakyat Daerah Kota Surabaya Tahun 2014 yaitu sebanyak 34\% (tiga puluh empat persen) keterwakilan perempuan menduduki Kursi Dewan Perwakilan Rakyat Daerah Kota Surabaya (Komisi Pemilihan Umum Kota Surabaya, 2014). Namun ada yang perlu digaris bawahi, walaupun kuota 30\% (tiga puluh persen) keterwakilan perempuan di Kursi Dewan Perwakilan Rakyat Daerah Kota Surabaya telah mencapai 34\% (tiga puluh empat persen), faktanya pada beberapa Daerah Pemilihan Surabaya kuota 30\% (tiga puluh persen) keterwakilan wanita ini belum terpenuhi (Komisi Pemilihan Umum Kota Surabaya, 2014). Pada Daerah Pemilihan Surabaya 1 (Bubutan, Genteng, Gubeng, Krembangan, Simokerto, 
dan Tegalsari) dan Daerah Pemilihan Surabaya 5 (Asemrowo, Benowo, Dukuh Pakis, Karangpilang, Lakarsantri, Pakal, Sambikerep, Tandes, dan Wiyung), kuota 30\% (tiga puluh persen) keterwakilan wanita ini belum terpenuhi secara maksimal. (KPU, 2014). Hal ini menjadi perhatian tersendiri bagi penulis. Oleh sebab itu, melihat belum maksimalnya keterwakilan perempuan di Kursi Dewan Perwakilan Rakyat Daerah Kota Surabaya, khususnya Daerah Pemilihan Surabaya 1 (Bubutan, Genteng, Gubeng, Krembangan, Simokerto, dan Tegalsari.

\section{METODE PENELITIAN}

Dalam penelitian ini penulis menggunakan pendekatan deskriptif kuantitatif yang bertujuan untuk menjawab rumusan masalah tentang bagaimanakah Partisipasi Perempuan di Kursi DPRD Kota Surabaya melalui Kebijakan Affirmative Action (Studi Pada Analisa Hasil Pemilihan Umum Tahun 2014). Rancangan pada penelitian ini nantinya akan berupa hasil, yang dimana pada prosesnya akan di analisis dengan menggunakan model implementasi kebijakan menurut Daniel Mazmanian dan Paul A. Sabatier. Model implementasi yang dimaksud meliputi beberapa variable, antara lain: (1) Kemudahan Suatu Masalah Dikendalikan (2) Kemampuan Kebijakan dalam Menstrukturkan Proses Implementasi Kebijakan, dan (3) Variabel-variabel di Luar Undang-Undang Yang Mempengaruhi Implementasi Kebijakan (Sulastri, 2009).

Subjek pada penelitian ini adalah 13 (tigabelas) responden dari 12 (duabelas) partai politik peserta pemilihan umum tahun 2014, meliputi Partai Nasdem, Partai Kebangkitan Bangsa, Partai Keadilan Sejahtera, Partai Demokrasi Indonesia Perjuangan, Partai Golongan Karya, Partai Gerakan Indonesia Raya, Partai Demokrat, Partai Amanat Nasional, Partai Persatuan Pembangunan, Partai Hati Nurani Rakyat, Partai Bulan Bintang dan Partai Keadilan dan Persatuan Indonesia. Populasi dan pengambilan sampel pada penelitian ini dilakukan dengan berdasarkan pada teori dari Arikunto \& Suharsimi (2010). Adapun total daftar calon sementara dan daftar calon tetap dari 12 (duabelas) partai politik peserta pemilihan. umum tahun 2014 berjumlah 129 (seratus dua puluh sembilan) orang (Komisi Pemilihan Umum, 2014). Artinya lebih dari 100 (seratus) orang. Maka, perhitungannya 10\% dari 129 orang adalah 13 orang sampel sebagai responden yang akan diambil dari 12 (dua belas) partai politik peserta Pemilu. Kemudian untuk pengambilan sampel pada responden pada penelitian ini, akan dilakukan dengan menggunakan metode snowball sampling. Di sisi lain, untuk fokus dan objek penelitian ini sendiri meliputi :

1. Proses pendaftarann Bakal Calon Anggota DPRD Kota Surabaya Tahun 2014.

2. Proses Penetapan DCS Anggota DPRD Kota Surabaya Tahun 2014.

3. Proses Penetapan DCT Anggota DPRD Kota Surabaya Tahun 2014.

Teknik pengumpulan data pada penelitian ini berupa observasi, dokumentasi, dan kuesioner/angket tertutup. Sedangkan untuk instrumen pada penelitian ini meliputi, pertama berupa kuesioner atau angket yang memuat daftar pertanyaan tertulis terkait topik. Kedua, buku catatan dan yang terakhir adalah alat komunikasi atau media digital seperti handphone atau kamera yang digunakan saat mengambil data berupa foto maupun video, serta digunakan untuk merekam suara. Di sisi lain, untuk teknik analisis data dalam penelitian ini menggunakan teknik analisis data kuantitatif dengan skala pengukuran, tepatnya yaitu skala likert. Setelah proses pengumpulan data selesai, maka akan diperoleh data kuantitatif yang siap untuk dianalisis dan dijabarkan secara keseluruhan, sehingga menghasilkan sebuah kesimpulan

\section{HASIL DAN PEMBAHASAN}

\section{Kemudahan suatu masalah Dikendalikan}

\section{a) Kesukaran-Kesukaran Teknis}

Berbicara mengenai indikator kesukaran-kesukaran teknis, dimana pada indikator ini dijelaskan oleh Mazmanian dan Sabatier bahwa tercapai atau tidaknya tujuan sebuah program dalam proses implementasi kebijakan, bergantung pada 
beberapa persyaratan teknis yang harus dipenuhi. Salah satunya, yaitu terkait pemahaman tentang prinsip hubungan sebab-akibat yang mempengaruhi masalah (Agustino, 2014). Pada proses implementasi kebijakan 30\% (tiga puluh persen) keterwakilan perempuan ini, kemudian ditemukan beberapa masalah atau kesukaran-kesukaran teknis didalamnya, meliputi:

1. Kurangnya persiapan partai politik terkait jumlah perempuan yang akan diajukan sebagai bakal calon dalam Pemilu. Ini kaitannya dengan partai politik yang harus memperhatikan paling sedikit 30\% (tiga puluh persen) keterwakilan perempuan.

2. Ditemukannya kerumitan pada saat proses verifikasi kelengkapan dan kebenaran dokumen persyaratan administratif bakal calon. Hal ini terkait dengan kuota 30\% (tiga puluh persen) keterwakilan perempuan yang masih belum terpenuhi, serta ditemukannya bakal calon yang masih belum memenuhi persayaratan dokumen adminsitratif.

3. Ada partai politik yang tidak dapat memberikan klarifikasi dan tidak dapat memenuhi syarat yang diajukan oleh masyarakat, terkait masukan dan tanggapan masyarakat terhadap susunan daftar calon sementara.

4. Ditemukannya, partai politik maupun Bakal Calon Anggota atau Calon Anggota DPRD yang tidak mengetahui tahapan alur dari proses pendaftaran bakal calon, alur dari proses penetapan Daftar Calon Sementara dan alur dari proses penetapan Daftar Calon Tetap Anggota DPRD Kota Surabaya.

5. Adanya beberapa bakal calon yang tidak lolos atau tidak terverifikasi menjadi Daftar Calon Sementara Anggota DPRD Kota Surabaya. Serta, ditemukannya data bahwa ada beberapa Daftar Calon Sementara yang tidak lolos atau tidak terverifikasi menjadi Daftar Calon Tetap Anggota DPRD Kota Surabaya. Sehingga hal ini semakin memperlambat proses penetapan, baik penetapan Daftar Calon Sementara maupun proses penetapan Daftar Calon Tetap Anggota DPRD.

Berdasarkan pembahasan hasil dapat disimpulkan bahwa indikator kesukaran-kesukaran teknis menurut Mazmanian dan Sabatier ini telah dianalisis dan terjawab (Agustino, 2014). Hal ini diartikan bahwa, terverifikasi atau tidaknya, dan lolos atau tidaknya seorang Bakal Calon atau Calon Anggota DPRD Kota Surabaya tergantung pada kemampuan dalam melaksanakan dan memenuhi ketetapan atau kebijakan pelaksanaan Pemilu.

\section{b) Keragaman perilaku kelompok sasaran}

Dalam penelitian ini, yang menjadi kelompok sasarannya adalah partai politik, bakal calon, dan calon Anggota DPRD. Dimana, Mazmanian dan Sabatier menjelaskan bahwa, keberagaman perilaku yang diatur disini dimaksudkan, apabila semakin beragam perilaku yang diatur dan semakin beragam perilaku pelayanan yang diberikan, maka akan semakin sulit untuk membuat peraturan yang tegas dan jelas. Sehingga, mau tidak mau tentunya dibutuhkan suatu dasar hukum untuk mengaturnya (Agustino, 2014).

Dalam proses pengimplementasian kebijakan keterwakilan perempuan ini, tentunya memiliki dasar hukum yang melatarbelakanginya, apalagi dasar hukum ini merupakan syarat yang harus dipenuhi oleh partai politik dan bakal calon, maka partai politik dan bakal calon harus rela untuk menerima peraturan tersebut. Dengan diperlehnya fakta bahwa, kuota $30 \%$ (tiga puluh persen) keterwakilan perempuan ini telah terpenuhi, maka secara tidak langsung dapat dikatakan bahwa partai politik telah patuh dan mendukung kebijakan ini.

Di sisi lain, dengan beragamnya perilaku kelompok sasaran yang diatur, hal ini tidak membuat kelompok sasaran yaitu partai politik, bakal calon atau calon anggota DPRD menerima dengan mudah dan begitu saja setiap keputusan yang ditetapkan oleh Komisi Pemilihan Umum Kota Surabaya terkait hasil Daftar Calon Sementara dan hasil penetapan Daftar Calon Tetap Anggota Dewan Perwakilan Rakyat Daerah Kota Surabaya.

Berdasarkan pembahasan hasil dapat disimpulkan bahwa indikator keragaman perilaku kelompok sasaran menurut Mazmanian dan Sabatier telah dianalisis dan terjawab. Sehingga dapat diartikan bahwa, keragaman perilaku kelompok sasaran pada indikator ini telah patuh terhadap kebijakan. Walaupun, nantinya masih akan ditemukan beberapa keputusan yang menimbulkan ketidaksepakatan, namun sampai sejauh ini dengan terpenuhinya kuota 30\% (tiga puluh persen) keterwakilan perempuan, artinya indikator ini telah terpenuhi (Agustino, 2014). 


\section{c) Persentase kelompok sasaran dibanding jumlah penduduk}

Partai politik Peserta Pemilu, maupun Bakal Calon Anggota DPRD, tentunya membutuhkan partisipasi dari masyarakat. Artinya, hal ini berkaitan dengan hak pilih masyarakat Kota Surabaya itu sendiri. Mazmanian dan Sabatier menjelaskan bahwa semakin kecil dan semakin jelas (dapat dibedakan dari kelompok lain), kelompok sasaran yang perilakunya akan diubah, maka semakin besar pula peluang untuk menyalurkan dukungan politik terhadap program atau kebijakan. Dengan demikian, akan lebih terbuka peluang bagi pencapaian tujuan kebijakan.

Berdasarkan data yang dihimpun oleh Komisi Pemilihan Umum Kota Surabaya pada Pemilu tahun 2014, sebanyak 50 Calon Terpilih Anggota Dewan Perwakilan Rakyat Daerah Kota Surabaya, dengan rincian 33 orang laki-laki dan 17 orang perempuan. Jumlah total keterwakilan perempuan sebanyak 34\% (tiga puluh empat persen). Selanjutnya dijelaskan bahwa hasil penetapan Daftar Calon Sementara dan Daftar Calon Tetap Anggota Dewan Perwakilan Rakyat Daerah Kota Surabaya telah mencapai bahkan melebihi kuota 30\% (tiga puluh persen) keterwakilan perempuan. Hal ini berarti partai politik peserta Pemilu telah bekerja keras untuk memenuhi kebijakan ini.

Disisi lain, perlu diketahui bersama bahwa jumlah perempuan sebagai Bakal Calon atau Calon Anggota Dewan Perwakilan Rakyat Daerah Kota Surabaya sangat berpengaruh terhadap susunan daftar calon lainnya. Oleh sebab itu, partai politik harus benar-benar memperhatikannya, agar tidak terjadi kesalahan yang berdampak pada partai politik itu sendiri. Seperti harus bongkar pasang susunan daftar calon karena jumlah perempuan yang kurang atau munculnya permasalahan terhadap calon perempuan.

Dengan demikian dapat disimpulkan bahwa indikator presentase kelompok sasaran dibanding jumlah penduduk menurut Mazmanian dan Sabatier ini telah dianalisis dan terjawab. Dimana, baik dari sudut pandang masyarakat, partai politik maupun Calon Anggota Dewan Perwakilan Rakyat Daerah Kota Surabaya memiliki peran masing-masing terhadap indikator ini. Apalagi, terkait keterwakilan perempuan sebagai Calon Anggota Dewan Perwakilan Rakyat Daerah Kota Surabaya yang menjadi sasaran dalam kebijakan ini.

\section{d) Tingkat dan ruang lingkup perubahan perilaku yang dikehendaki}

Pada indikator tingkat dan ruang lingkup perubahan perilaku yang dikehendaki ini, Mazmanian dan Sabatier menjelaskan bahwa semakin besar jumlah perubahan perilaku yang dikehendaki, maka semakin sukar untuk memperoleh keberhasilan dalam implementasi kebijakan (Abdul Wahab, 2015). Hal ini pun berkaitan dengan perubahan perilaku partai politik yang harus patuh dan mampu untuk memenuhi, serta melaksanakan kebijakan $30 \%$ (tiga puluh persen) keterwakilan perempuan.

Pada indikator tingkat dan ruang lingkup perubahan perilaku yang dikehendaki ini, diperoleh fakta bahwa, tidak semua atau hanya beberapa saja partai politik peserta Pemilu yang mengalami kesulitan terkait pemenuhan kuota 30\% (tiga puluh persen) keterwakilan perempuan ini. Sisanya tidak mengalami masalah, bahkan mendukung dengan adanya kebijakan ini.

Berdasarkan pemaparan datas, dapat disimpulkan bahwa peran suatu landasan atau peraturan dalam sebuah kebijakan sangatlah penting. Dengan adanya landasan dan peraturan dalam suatu kebijakan, akan berdampak bagi pihak-pihak yang bersangkutan. Seperti halnya, partai politik peserta Pemilu dan Bakal Calon atau Calon Anggota Dewan Perwakilan Rakyat Daerah Kota Surabaya yang telah berhasil melaksanakan dan berhasil pula memenuhi kuota $30 \%$ (tiga puluh persen) keterwakilan perempuan ini.

Di sisi lain, diperoleh kebenaran bahwa sikap dan perilaku dari sasaran kebijakan memang tidak semuanya bersedia untuk mendukung kebijakan keterwakilan perempuan ini. Namun, karena kebijakan keterwakilan perempuan ini berlandaskan pada peraturan, yaitu UndangUndang No. 8 Tahun 2012 Tentang Pemilihan Umum Anggota Dewan Perwakilan Rakyat, Dewan Perwakilan Daerah, dan Dewan Perwakilan Rakyat Daerah. Maka, perubahan sikap dan perilaku untuk melaksanakan kebijakan ini pun terjadi. Dimana, ini dibuktikan dengan hasil implementasi kebijakan 30\% (tiga puluh persen) keterwakilan perempuan dalam Daftar Calon Sementara dan dalam Daftar Calon Tetap Anggota Dewan Perwakilan Rakyat Daerah Kota Surabaya telah terpenuhi. 


\section{Kemampuan Kebijakan dalam Menstrukturkan Proses Implementasi Kebijakan}

\section{a) Kecermatan dan kejelasan penjenjangan tujuan-tujuan resmi yang akan dicapai}

Pada indikator kecermatan dan kejelasan penjenjangan tujuan-tujuan resmi yang akan dicapai, Mazmanian dan Sabatier menjelaskan bahwa tujuan resmi yang dirumuskan dengan cerdas dan cermat serta disusun secara jelas sangat berperan penting sebagai alat bantu untuk menilai suatu kebijakan, sebagai pedoman konkret aktor-aktor pelaksana dan sebagai sumber dukungan bagi tujuan itu sendiri (Abdul Wahab, 2015). Hal ini pun berlaku bagi tujuan implementasi kebijakan 30\% (tiga puluh persen) keterwakilan perempuan.

Partai politik dan Bakal Calon atau Calon Anggota DPRD pun selayaknya harus mengerti dan juga sadar dengan tujuan dari diimplementasikan kebijakan ini. Salah satunya yaitu untuk meningkatkan jumlah partisipasi perempuan di Kursi DPRD Kota Surabaya. Pada indikator kecermatan dan kejelasan penjenjangan tujuan-tujuan resmi yang akan dicapai, menurut Mazmanian dan Sabatier (dalam Abdul Wahab, 2015), tepatnya pada proses pendaftaran Bakal Calon Anggota DPRD, proses penetapan Daftar Calon Sementara Anggota DPRD, dan proses penetapan Daftar Calon Tetap Anggota DPRD telah terpenuhi. Walaupun ada beberapa partai politik yang pas memenuhi 30\% (tiga puluh persen) keterwakilan perempuan dan ada pula yang melebihi $45 \%$ (empat puluh lima persen), bahkan hingga 50\% (lima puluh persen) keterwakilan perempuan.

\section{b) Keterandalan teori kausalitas yang diperlukan}

Pada indikator keterandalan teori kausalitas yang diperlukan, menurut Mazmanian dan Sabatier menjelaskan bahwa teori kausalitas merupakan konstribusi yang penting dalam analisis implementasi kebijakan, karena dengan adanya teori kausalitas akan sangat membantu dalam mendeskripsikan tentang bagaimana cara untuk mencapai tujuan-tujuan yang dikehendaki (Agustino, 2014). Perlu diketahui bahwa, sebelum program atau kebijakan di implementasikan, tentu ada sebab-akibat yang melatar belakangi kebijakan baru di implementasikan. Hal ini pun berlaku bagi kebijakan 30\% (tiga puluh persen) keterwakilan perempuan.

Pada dasarnya, sebelum kebijakan 30\% (tiga puluh persen) keterwakilan perempuan ini diimplementasikan, tingkat partisipasi perempuan di Kursi DPRD Kota Surabaya masih dibawah 30\% (tiga puluh persen). Kemudian, setelah dikeluarkannya kebijakan ini pada tahun 2003 untuk menyambut Pemilu di tahun 2004, tingkat keterwakilan perempuan di Kursi DPRD naik menjadi 30\% (tiga puluh persen). Selanjutnya, pada Pemilu tahun 2014 keterwakilan perempuan ini naik kembali menjadi 34\% (tiga puluh empat persen). Walaupun ada beberapa partai politik yang pada saat proses pendaftaran Bakal Calon Anggota DPRD, proses penetapan Daftar Calon Sementara Anggota DPRD, dan proses penetapan Daftar Calon Tetap Anggota DPRD hanya memenuhi kuota pas 30\% (tiga puluh persen). Namun, ada pula yang melebihi 45\% (empat puluh lima persen), bahkan hingga 50\% (lima puluh persen) keterwakilan perempuan. Disisi lain, Partai Politik dan Bakal Calon atau Calon Anggota DPRD Kota Surabaya selain merasakan adanya dampak positif, seperti dengan meningkatnya jumlah peresentase keterwakilan perempuan pada Daftar Calon Terpilih Anggota DPRD Kota Surabaya, yaitu sebanyak 34\% (tiga puluh empat persen). Adapun dampak negatif lainnya yang dirasakan, seperti sukarnya mencari calon anggota legislatif perempuan. Berdasarkan pemaparan diatas, maka indikator keterandalan teori kausalitas yang diperlukan, menurut Mazmanian dan Sabatier ini telah terjawab.

\section{c) Ketepatan alokasi sumber dana}

Pada indikator ketepatan alokasi sumberdana ini, tentunya tidak dapat dipungkiri lagi bahwa, alokasi dana merupakan salah satu faktor penunjang yang penting dalam pelaksanaan sebuah kebijakan. Pernyataan ini pun di dukung oleh pendapat dari Mazmanian dan Sabatier menjelaskan bahwa dengan tersedianya alokasi dana dalam proses implementasi kebijakan, maka usaha untuk mencapai tujuan kebijakan pun semakin mudah (Agustino, 2014).Hal ini tentunya juga berlaku bagi implementasi kebijakan 30\% (tiga puluh persen) keterwakilan 
perempuan, yang merupakan serangkaian kebijakan dalam proses pelaksanaan Pemilu.

Berdasarkan hasil kuesioner penulis, diperoleh fakta bahwa Komisi Pemilihan Umum Kota Surabaya memiliki 2 (dua) bentuk alokasi dana yang tersedia. Pertama, berbasis anggaran dan kedua berbasis non anggaran. Alokasi dana berbasis anggaran maksudnya sesuai dengan yang ada di DIPA. Sedangkan, untuk yang berbasis non anggaran artinya tidak ada anggaran yang tersedia atau tidak tersedia di DIPA. Masih berkaitan dengan pengalokasian sumber dana, selain Komisi Pemilihan Umum Kota Surabaya sebagai penyelenggara kebijakan yang memiliki alokasi dana dalam proses implementasi, partai politik dan Bakal Calon atau Calon Anggota DPRD Kota Surabaya juga memiliki alokasi dana tersendiri dalam proses pelaksanaan pemilihan umum ini.

Indikator ketepatan alokasi sumberdana menurut Mazmanian dan Sabatier ini telah terjawab. Sehingga dapat diartikan bahwa, alokasi sumberdana merupakan salah satu unsur terpenting dalam proses pelaksanaan sebuah kebijakan. Pada setiap instansi atau lembaga tentunya memiliki alokasi sumberdana tersendiri dalam mejalankan kebijakan maupun tugas pokok dan fungsinya.

\section{d) Keterpaduan hierarki di dalam lingkungan dan di antara lembaga- lembaga/instansi pelaksana}

Pada indikator keterpaduan hierarki di dalam lingkungan dan diantara lembaga-lembaga pelaksana. Dimana, Mazmanian dan Sabatier menjelaskan bahwa salah satu ciri penting yang perlu dimiliki oleh setiap peraturan perundangan yang baik ialah kemampuan untuk menyatupadukan hierarki dari badan-badan pelaksana (Agustino, 2014). Ketika kemampuan dalam menyatupadukan tidak dapat dilaksanakan, maka kegagalan koordinasi antar instansi akan mengagalkan tujuan dari kebijakan yang telah ditetapkan.

Hal ini pun berlaku bagi Komisi Pemilihan Umum Kota Surabaya dan partai politik peserta Pemilu. Dimana, dalam pelaksanaan implementasi kebijakan 30\% (tiga puluh persen) keterwakilan perempuan pada proses pendaftaran Bakal Calon Anggota Dewan Perwakilan Rakyat Daerah Kota Surabaya, proses penetapan Daftar Calon Sementara hingga proses penetapan Daftar Calon Tetap Anggota Dewan Perwakilan Rakyat Daerah Kota Surabaya yang masuk dalam serangkaian kegiatan Pemilu, tentu dibutuhkan koordinasi yang baik antara Komisi Pemilihan Umum Kota Surabaya dan partai politik peserta Pemilu, agar implementasi kebijakan ini dapat berjalan sesuai tujuan dan tentunya tepat sasaran.

Koordinasi dimaksudkan disini, biasanya direalisasikan dalam bentuk sosialisasi, dan bimtek. Apabila yang peserta Pemilu yang bersangkutan masih mengalami kesulitan dan kebingungan atau ingin bertanya maupun berdiskusi terkait tahap-tahap atau proses pencalonan, proses penyusunan Daftar Calon Sementara serta proses penetapan Daftar Calon Tetap Anggota Dewan Perwakilan Rakyat Daerah Kota Surabaya, dapat langsung mengunjungi Kantor Komisi Pemilihan Umum Kota Surabaya untuk berdiskusi.

Indikator keterpaduan hierarki di dalam lingkungan dan diantara lembaga- lembaga pelaksana menurut Mazmanian dan Sabatier ini telah terjawab. Sehingga dapat diartikan bahwa, upaya sinkronisasi dan koordinasi yang baik antar lembaga penyelenggara kebijakan maupun pelaksana kebijakan merupakan hal yang amat penting untuk dilakukan. Karena, hal ini merupakan suatu usaha dalam menyamakan persepsi agar, satu tujuan dan tepat sasaran dalam menyukseskan implementasi kebijakan tersebut.

\section{e) Aturan-aturan pembuatan keputusan dari badan-badan pelaksana}

Pada indikator aturan-aturan pembuatan keputusan dari badan-badan pelaksana, yang dipaparkan oleh Mazmanian dan menjelaskan bahwa adanya aturan dalam proses implementasi kebijakan dapat memberikan konsistensi dan kejelasan tujuan, serta memperkecil jumlah penolakan terhadap implementasi kebijakan, yang nantinya akan berdampak pada kepatuhan kelompok-kelompok sasaran (Agustino, 2014). Hal ini juga berlaku bagi implementasi kebijakan 30\% (tiga puluh persen) keterwakilan perempuan.

Dalam proses implementasi kebijakan 30\% (tiga puluh persen) keterwakilan perempuan pada pelaksanaan Pemilu tahun 2014, baik partai politik dan Bakal Calon atau Calon Anggota DPRD seharusnya wajib mengetahui landasan hukum dalam proses pelaksanaan Pemilu. Dasar hukum yang dimaksudkan meliputi, Undang-Undang No. 8 Tahun 2012 
Tentang Pemilihan Umum Anggota Dewan Perwakilan Rakyat, Dewan Perwakilan Daerah, dan Dewan Perwakilan Rakyat Daerah dan PKPU (Peraturan Keputusan Komisi Pemilihan Umum) ditahun tersebut, serta surat keputusan lainnya, seperti Surat Keputusan tentang Penetapan Daftar Calon Semenetara dan Daftar Calon Tetap Anggota DPRD Kota Surabaya yang dikeluarkan oleh Komisi Pemilihan Umum Kota Surabaya.

Berdasarkan hasil kuesioner dan hasil pemaparan diatas, dapat disimpulkan bahwa dalam proses implementasi kebijakan, peraturan atau dasar hukum memang sangat penting dan sangat dibutuhkan dalam pelaksanaan suatu kebijakan. Dengan adanya peraturan maupun dasar hukum yang melatarbelakangi suatu kebijakan. Maka setiap keputusan yang diambil oleh badan pelaksana, misalnya saja Komisi Pemilihan Umum Kota Surabaya akan semakin kuat dan dapat dipertanggungjawabkan.

\section{f) Kesepakatan para pejabat terhadap tujuan yang termaktub dalam undang-undang}

Pada indikator kesepakatan para pejabat terhadap tujuan yang termaktub dalam undangundang. Dimana, Mazmanian dan Sabatier menjelaskan bahwa para pejabat pelaksana memiliki kesepakatan yang diperuntukkan guna tercapainya suatu tujuan (Agustino, 2014). Hal ini sangat signifikan tentunya, karena topdown policy bukan hal yang mudah untuk diimplementasikan pada para pejabat pelaksana daerah atau lokal.

Hal ini juga berlaku bagi implementasi kebijakan 30\% (tiga puluh persen) keterwakilan perempuan pada proses pendaftaran Bakal Calon Anggota Dewan Perwakilan Rakyat Daerah Kota Surabaya, proses penetapan Daftar Calon Sementara hingga proses penetapan Daftar Calon Tetap Anggota Dewan Perwakilan Rakyat Daerah Kota Surabaya. Dimana, dibutuhkan komitmen dan kesepakatan antara Komisi Pemilihan Umum Kota Surabaya dan partai politik peserta Pemilu, untuk mencapai tujuan dari kebijakan 30\% (tiga puluh persen) keterwakilan perempuan ini sendiri.

Berdasarkan pembahasan hasil kuesioner dan analisis penulis, dapat disimpulkan bahwa indikator kesepakatan para pejabat terhadap tujuan yang termaktub dalam undang-undang menurut Mazmanian dan Sabatier telah terjawab. Dimana, komitmen dan kesepakatan antara Komisi Pemilihan Umum Kota Surabaya, partai politik peserta Pemilu dan Bakal Calon atau Calon Anggota DPRD memang sangat penting untuk dibentuk. Dengan terbentuknya komitmen, maka akan terbentuk pula rasa saling percaya antara lembaga penyelenggara maupun lembaga pelaksana yang bersangkutan guna menyukseskan tujuan dari implementsi kebijakan ini.

\section{g) Akses formal pihak-pihak luar}

Pada indikator akses formal pihak-pihak luar, dimana Mazmanian dan Sabatier berpendapat bahwa faktor yang dapat mempengaruhi proses implementasi kebijakan, salah satunya ialah sampai sejauhmana kesempatan berpartisipasi terbuka bagi para aktor di luar badan-badan pelaksana dapat mempengaruhi para pendukung tujuan resmi. Ini dimaksudkan, agar kontrol pada para pejabat pelaksana dapat berjalan sebagaimana yang telah ditetapkan (Agustino, 2014). Hal ini pun berlaku bagi Komisi Pemilihan Umum Kota Surabaya.

Akses formal publik khususnya terkait informasi seputar Pemilu maupun kinerja Komisi Pemilihan Umum Kota Surabaya sangat terbuka lebar. Dimana, baik masyarakat umum, partai politik, dan Bakal Calon atau Calon Anggota DPRD dapat mengaksesnya melalui web KPU Kota Surabaya yang telah tersedia. Apabila informasi yang disediakan di web kurang memuaskan, maka dapat langsung mengunjungi kantor KPU Kota Surabaya untuk bertanya atau berdiskusi.

Berdasarkan hasil riset dapat disimpulkan bahwa indikator akses formal pihak-pihak luar, menurut Mazmanian dan Sabatier telah terjawab. Dengan demikian dapat diartikan bahwa akses formal maupun partisipasi dari pihak luar, baik masyarakat umum, partai politik peserta Pemilu dan Bakal Calon atau Calon Anggota DPRD sangat dibuka lebar oleh Komisi Pemilihan Umum Kota Surabaya. Selain itu, dengan dibukanya akses formal maupun partisipasi dari pihak luar, maka kinerja Komisi Pemilihan Umum dapat diawasi dan dapat dikontrol oleh partai politik peserta Pemilu dan masyarakat maupun lembaga pelaksana yang berkepentingan lainnya. 


\section{Variabel-variabel di Luar Undang-Undang Yang Mempengaruhi Implementasi Kebijakan}

\section{a) Kondisi sosial-ekonomi dan teknologi}

Pada indikator kondisi sosial, ekonomi dan teknologi menurut Mazmanian dan Sabatier dijelaskan bahwa, adanya perubahan waktu dan perbedaan wilayah-wilayah hukum pemerintah dari segi kondisi sosial, ekonomi, dan teknologi sangat berpengaruh terhadap upaya pencapaian tujuan yang telah ditetapkan oleh undang-undang (Agustino, 2014). Karena itu, faktor eksternal juga menjadi hal penting untuk diperhatikan guna keberhasilan implementasi kebijakan.

Kondisi atau keadaan yang mempengaruhi kinerja pegawai Komisi Pemilihan Umum Kota Surabaya dalam serangkaian proses pelaksanaan Pemilu, tentunya dapat dirasakan oleh partai politik atau Bakal Calon atau Calon Anggota DPRD sebagai penerima pelayanan. Kondisi-kondisi ini bisa saja karena faktor kelelahan atau adanya masalah pribadi yang ikut terbawa ke kantor. Sehingga mempengaruhi mood dan sikap pegawai di kantor Komisi Pemilihan Umum Kota Surabaya yang dapat mempengaruhi kinerjanya. Berdasarkan hasil kuesioner dan hasil analisis penulis, indikator kondisi sosial- ekonomi dan teknologi ini memang sangat berpangaruh terhadap kinerja seorang pegawai. Oleh sebab itu, setiap pegawai harus mampu menjalin hubungan yang baik dengan lingkungan sosial dan mampu bersikap profesional dalam keadaan apapun itu, guna menciptakan pelayanan yang baik.

Di sisi lain apabila dikaji dari segi teknologi, menurut penulis Komisi Pemilihan Umum Kota Surabaya sudah mampu untuk merealisasikannya. Hal ini terlihat dari aktifnya web KPU yang dimiliki oleh Komisi Pemilihan Umum Kota Surabaya. Ditambah lagi, Komisi Pemilihan Umum Kota Surabaya juga menggunakan jasa media pers dalam mensosialisasikan, dan memberikan informasi, serta meliput kegiatan selama pelaksanaan Pemilu berlangsung. Dengan adanya pers, tentunya sangat membantu memberikan informasi kepada partai politik dan Bakal Calon atau Calon Anggota DPRD dalam proses pendaftaran Bakal Calon Anggota DPRD, proses penetapan Daftar Calon Sementara Anggota DPRD, dan proses penetapan Daftar Calon Tetap Anggota DPRD. Adanya keterlibatan pers juga sangat mempermudah partai politik, dan Bakal Calon atau Calon Anggota DPRD dalam mencari informasi dan memantau hasil dari serangkaian proses pelaksanaan Pemilu.

\section{b) Dukungan Publik}

Pada indikator dukungan publik, Mazmanian dan Sabatier menjelaskan bahwa, untuk mendorong tingkat keberhasilan implementasi kebijakan, sangat dibutuhkan sentuhan dan dukungan dari publik (Agustino, 2014). Publik disini ditunjukkan kepada partai politik, dan Bakal Calon atau Calon Anggota DPRD.

Dimana, berdasarkan hasil kuesioner dan hasil analisis penulis diperoleh fakta bahwa, tidak semua partai politik dan Bakal Calon atau Calon Anggota DPRD mendukung kebijakan ini. Sehingga, dapat dikatakan bahwa, ada beberapa partai politik dan Bakal Calon atau Calon Anggota DPRD yang mendukung kebijakan ini, dan ada pula partai politik dan Bakal Calon atau Calon Anggota DPRD yang kurang mendukung kebijakan ini. Namun, tidak dapat dipungkiri juga bahwa, baik partai politik dan Bakal Calon atau Calon Anggota DPRD pun berusaha semaksimal mungkin untuk terus mendukung setiap tahap dalam proses pendaftaran atau pengajuan Bakal Calon Anggota DPRD, proses penetapan Daftar Calon Sementara, hingga proses penetapan Daftar Calon Tetap Anggota DPRD Kota Surabaya.

Berdasarkan hasil pemaparan diatas, dapat disimpulkan bahwa, indikator dukungan publik menurut Mazmanian dan Sabatier dalam Agustino (2014) ini telah terjawab. Sehingga dapat diartikan bahwa, dukungan yang diberikan baik berasal dari partai politik dan Bakal Calon atau Calon Anggota DPRD sebagai sasaran dan pelaksana kebijakan 30\% (tiga puluh persen) keterwakilan perempuan dalam serangkaian pelaksanaan Pemilu ini, memang sangat dibutuhkan. Karena, apabila partai politik, dan Bakal Calon atau Calon Anggota DPRD tidak mendukung atau bahkan menentang dan menolak kebijakan ini, maka kebijakan ini akan gagal untuk diimplementasikan. 


\section{c) Sikap dan sumber yang dimiliki kelompok-kelompok}

Pada indikator sikap dan sumber yang dimiliki oleh kelompok-kelompok, dimana Mazmanian dan Sabatier menjelaskan bahwa, adanya perubahan-perubahan tertentu pada sikap kelompok terhadap tujuan undang-undang juga berperan penting dalam proses implementasi (Abdul Wahab, 2015). Undang-undang sendiri lahir sebagai akibat dari semakin kuatnya keprihatinan kelompok terhadap masalah-masalah yang terjadi. Hal ini juga berlaku bagi implementasi kebijakan 30\% (tiga puluh persen) keterwakilan perempuan. Dimana, kebijakan keterwakilan perempuan ini lahir sebagai akibat dari kurangnya partisipasi perempuan di ranah politik maupun pengambil keputusan.

Berdasarkan hasil kuesioner dan hasil analisis penulis diperoleh fakta bahwa, kuota $30 \%$ (tiga puluh persen) keterwakilan perempuan ini telah terpenuhi bahkan melebihi. Hal ini tentunya membuktikan bahwa, adanya perubahan sikap, perilaku, dan sumber yang dimiliki kelompok-kelompok terutama partai poltik dan Bakal Calon atau Calon Anggota DPRD untuk mau mematuhi dan memenuhi kebijakan tersebut. Walaupun bersifat memaksa, namun kebijakan ini berlandaskan pada peraturan Undang-Undang No. 8 Tahun 2012 Tentang Pemilihan Umum Anggota Dewan Perwakilan Rakyat, Dewan Perwakilan Daerah, dan Dewan Perwakilan Rakyat Daerah. Di sisi lain, dengan terpenuhinya kuota 30\% (tiga puluh persen) keterwakilan perempuan ini. Artinya, dibutuhkan feedback dari Komisi Pemilihan Umum Kota Surabaya kepada partai politik dan Bakal Calon atau Calon Anggota DPRD melalui surat pemberitahuan. Surat pemberitahuan ini dimaksudkan sebagai bentuk kofirmasi atau pemberitahuan kepada partai politik apabila nantinya ditemukan bakal calon dan calon sementara yang belum terverifikasi dan belum memenuhi persyaratan.

Berdasarkan hasil kuesioner dan hasil pemaparan diatas, dapat disimpulkan bahwa, indikator sikap dan sumber yang dimiliki kelompok-kelompok menurut Mazmanian dan Sabatier dalam Abdul Wahab (2015) ini telah terjawab. Sehingga dapat diartikan bahwa, sikap dan sumber yang dimiliki kelompok-kelompok ini, secara tidak langsung telah ikut berpartisipasi dalam mendukung kebijakan ini. Hal ini dibuktikan dengan Hasil Pengajuan Bakal Calon Anggota DPRD, Hasil Daftar Calon Sementara dan Hasil Daftar Calon Tetap Anggota Dewan Perwakilan Rakyat Daerah Kota Surabaya telah memenuhi kuota 30\% (tiga puluh persen) keterwakilan perempuan. Artinya, partai politik peserta Pemilu memiliki sikap yang kondusif dan mau menerima kebijakan ini, walaupun secara terpaksa.

\section{d) Dukungan dari badan-badan/lembaga-lembaga atasan yang berwenang}

Pada indikator dukungan dari badan-badan/lembaga-lembaga atasan yang berwenang. Mazmanian dan Sabatier berpendapat bahwa, lembaga-lembaga atasan dari badan-badan pelaksana merupakan lembaga-lembaga yang mempunyai wewenang untuk melakukan kontrol dan memberikan dukungan terhadap kewenangan hukum dan sumber-sumber keuangan badan-badan pelaksana tersebut, serta terhadap tujuan undang- undang (Agustino, 2014). Lembaga berwenang yang dimaksud ini, juga harus mampu mengontrol pelaksanaan kebijakan 30\% (tiga puluh persen) keterwakilan perempuan dalam tahap pengajuan atau pendaftaran bakal calon, tahap penetapan Daftar Calon Sementara dan tahap penetapan Daftar Calon Tetap Anggota Dewan Perwakilan Rakyat Daerah Kota Surabaya dalam pelaksanaan Pemilu.

Berkaitan dengan hal tersebut, diperoleh fakta bahwa berdasarkan hasil kuesioner penulis, Partai politik dan Bakal Calon atau Calon Anggota DPRD, mendapatkan kontrol, respon positif dan dukungan dari Komisi Pemilihan Umum Kota Surabaya terkait implementasi kebijakan 30\% (tiga puluh persen) keterwakilan perempuan ini.

Berdasarkan pemaparan diatas, dapat dimpulkan bahwa dukungan dan kontrol dari lembaga atasan yang berwenang memang sangat penting untuk dilakukan. Hal ini bertujuan, agar peraturan dan kebijakan yang ditetapkan dalam persyaratan pelaksanaan Pemilu, khususnya terkait kuota 30\% (tiga puluh persen) keterwakilan perempuan dapat benar-benar diimplementasikan oleh Komisi Pemilihan Umum Kota Surabaya, partai politik peserta Pemilu dan Bakal Calon atau Calon Anggota DPRD Kota Surabaya. 


\section{e) Kesepakatan dan kemampuan kepemimpinan para pejabat pelaksana}

Pada indikator kesepakatan dan kemampuan kepemimpinan para pejabat pelaksana. Mazmanian dan Sabatier yang menjelaskan bahwa, variabel yang paling berpengaruh langsung terhadap output kebijakan ialah kesepakatan para pejabat badan pelaksana terhadap upaya mewujudkan tujuan undang-undang (Abdul Wahab, 2015).

Komitmen partai politik peserta Pemilu dalam menyukseskan serangkaian kegiatan Pemilu ini dapat dibuktikan secara nyata dengan terpenuhinya kuota $30 \%$ (tiga puluh persen) keterwakilan perempuan. Hal ini berdasarkan Hasil Pengajuan Daftar Bakal Calon Anggota DPRD, Hasil Penetapan Daftar Calon Sementara dan Hasil Penetapan Daftar Calon Tetap Anggota Dewan Perwakilan Rakyat Daerah Kota Surabaya. Selain itu, partai politik peserta Pemilu juga berusaha semaksimal mungkin untuk memenuhi setiap persyaratan dalam pelaksanaan Pemilu.

Di sisi lain, selain komitmen dari partai politik peserta Pemilu dan Bakal Calon atau Calon Anggota DPRD, komitmen dan kesepakatan lainnya juga dibentuk oleh Komisi Pemilihan Umum Kota Surabaya, dimana setiap output dari keputusan yang dihasilkan dapat dipegang dan tentunya juga dapat dipertanggungjawabkan.

Berdasarkan pembahasan hasil dapat disimpulkan bahwa indikator kesepakatan dan kemampuan kepemimpinan para pejabat pelaksana menurut Mazmanian dan Sabatier dalam Abdul Wahab (2015) ini telah terjawab. Sehingga dapat diartikan bahwa, baik komitmen dan kesepakatan dari partai politik peserta Pemilu dan Bakal Calon atau Calon Anggota DPRD maupun para pejabat Komisi Pemilihan Umum Kota Surabaya memang dapat dipertanggungjawabkan. Hal ini dibuktikan dengan terpenuhinya kuota 30\% keterwakilan perempuan berdasarkan Hasil Pengajuan Daftar Bakal Calon Anggota DPRD, Hasil Penetapan Daftar Calon Sementara dan Hasil Penetapan Calon Tetap Anggota Dewan Perwakilan Rakyat Daerah Kota Surabaya

\section{KESIMPULAN}

Dengan bantuan responden dari 12 (dua belas) partai politik peserta PEMILU, dapat disimpulkan bahwa, hasil analisis Implementasi Kebijakan Keterwakilan Perempuan di Kursi DPRD Kota Surabaya (Studi Pada Analisa Hasil Pemilihan Umum Tahun 2014) pada pelaksanaan Proses Pendaftaran Bakal Calon, Proses Penetapan DCS hingga Proses Penetapan DCT Anggota DPRD Kota Surabaya dalam Pemililu Tahun 2014, kebijakan 30\% (tiga puluh persen) keterwakilan perempuan ini telah tercapai. Bahkan, pada hasil daftar calon sementara dan hasil daftar calon tetap, tingkat keterwakilan perempuan ini telah melebihi kuota $30 \%$ (tiga puluh persen). Walaupun pada proses pelaksanaannya, peserta Pemilu dari 12 (duabelas) partai politik ini, banyak menemui masalah maupun kendala dalam memenuhi kebijakan ini.

Ada pula beberapa partai politik peserta Pemilu yang harus rela melakukan bongkar pasang terkait keterwakilan perempuan pada daftar bakal calon yang diajukan. Ini disebabkan, karena partai politik yang bersangkutan kurang melakukan persiapan sejak awal dan tidak menyiapkan jumlah kuota perempuan sesuai dengan kebijakan. Apalagi, seperti yang diketahui bahwa, bakal calon perempuan memang sangat berpengaruh terhadap daftar bakal calon lainnya. Sehingga, harus benar-benar diperhatikan.

\section{PENDANAAN}

Publikasi artikel ini menggunakan dana pribadi dari penulis.

\section{UCAPAN TERIMA KASIH}

Pertama-tama kami ucapkan terima kasih atas kepada civitas akademika Universitas Negeri Surabaya atas dukungannya sehingga artikel kami dapat di publish di Jurnal Kebijakan dan Manajemen Publik. 


\section{REFERENCES}

Abdul Wahab, S. (2015). Analisis Kebijakan: Dari Formulasi ke Penyusunan Model-Model Implementasi Kebijakan Publik. Bumi Aksara.

Amaliyah, I. (2018). Penguatan Keterwakilan Perempuan Dalam Kepengurusan Partai Politik Jurist-Diction 1 (1).164-181.

Agustino, L. (2014). Dasar-Dasar Kebijakan Publik. Alfabeta.

Budiardjo, M. (2010). Dasar-Dasar Ilmu Politik. Gramedia Pustaka Utama.

Ihromi, T. O., Irianto, S., \& Achie SudiartiLuh, L. (2006). Penghapusan Diskriminasi Terhadap Wanita. P.T. Alumni.

Komisi Pemilihan Umum Kota Surabaya. (2014). Keputusan Komisi Pemilihan Umum Kota Surabaya Nomor: 13/Ktps/KPU-Kota-014.329945/2014 Tentang Penetapan Perolehan Kursi Partai Politik Dan Calon Terpilih Anggota Dewan Perwakilan Rakyat Daerah Kota Surabaya Dalam Pemilihan Umum Tahun 2014. Surabaya.

Komisi Pemilihan Umum RI. (2019). Keterwakilan Perempuan di DPR RI Tertinggi pada Pemilu 2019. Retrieved from https://twitter.com/KPU_ID/status/11462683824482344 $96 ? \mathrm{~s}=08$
Nabila, A A, Fildanasari, Arham Alfandi (2019). Reformasi Keterwakilan Perempuan Di Parlemen Melalui Gayatri Curriculum Program Guna Meningkatkan Daya Saing Perempuan Dalam Ranah Politik. Jurnal Legislatif 2(2) $100-117$

Suharsimi \& Arikunto. (2010). Prosedur Penelitian Suatu Pendekatan Praktik. PT Rineka Cipta.

Sulastri. (2009). Analisis Implementasi. FISIP UI, 14-56.

Conflict of Interest Statement: The authors declare that the research was conducted in the absence of any commercial or financial relationships that could be construed as a potential conflict of interest.

Copyright (c) 2021 Yuni Lestari, Gading Gamaputra, Firdausi Nuzula. This is an open-access article distributed under the terms of the Creative Commons Attribution License (CC BY). The use, distribution or repro- duction in other forums is permitted, provided the original author(s) and the copyright owner(s) are credited and that the original publication in this journal is cited, in accordance with accepted academic practice. No use, distribution or reproduc- tion is permitted which does not comply with these terms. 